\title{
Evaluation of Heat Transfer Characteristics of Textile Goods by Infrared Image Measurement Method
}

\author{
MiYAmOтO Takeshi, IsHIZAwA Hiroaki*, NITTA Yuuki, KANAI Hiroyuki, TOBA Eiji \\ Faculty of Textile Science and Technology, Shinshu University, 3-15-1, Tokida, Ueda-shi, Nagano 386-8567, Japan
}

Received 15 July 2005; accepted for publication 8 October 2005

\begin{abstract}
This paper describes the infrared image heat measurement system for heat transferences of textile goods. The system consists of heat source, a series of optical apparatus, an infrared camera, and an image processor. This paper also describes that the model samples and several textile goods that were used for the developed measuring system are adequate for testing the time-dependent heat transferences of the materials. It is expected that the sensed information obtained by infrared image could evaluate the quality of the heat transferences more precisely and effectively than that by the conventional test methods.
\end{abstract}

Key Words: Infrared image, Heat absorption, Heat radiation, Thermal conductivity, Textile goods

\section{赤外画像計測法による繊維製品の熱移動特性評価}

宮本丈司，石澤広明 "，新田勇紀，金井博幸，鳥羽栄治

\section{1. 緒 言}

通常, 瀻維製品の熱移動特性評価として, 一般織物試験方 法[1]（JIS L 1096）における保温性測定[1]やKES（Kawabata Evaluation System）に扔ける定常熱伝導測定, 保温性測定が 用いられている[2]. これらの測定方法では試験片の温度差, 放熱量, 熱損失量等を測定し, それらより保温率, 熱伝導率 を計算することで瀻維製品に扔ける熱移動特性が評価され る.しかしながら, 熱の移動の直接的な観察は不可能であり, 時間的変化に対応することができない.

本研究ではこれらの問題点を解決するために, 赤外画像を 用いて様々な瀻維製品の熱移動特性について時系列的・定量 的に計測を行い, 赤外画像熱計測システムの瀻維分野への適 用を検討した。また，KESによる定常熱伝導性・保温性測定 の測定結果と比較を行い，本システムの妥当性について検討 した.

\section{2. 実験方法}

\section{1 測定原理}

全ての物質は温度に応じて電磁波として熱エネルギーを吸
収・放射している。この熱エネルギーの波長帯は近〜中赤外 域に存在するため, その波長带に対応する画像を撮影するこ とで熱移動に対応した画像を得ることができる[3]. 纎維製 品の熱移動特性評価として, 本研究では波長 8 $12 \mu \mathrm{m}$ に感 度を有する赤外カメラを用いて画像計測することで, 温度に 対応した輝度から熱移動特性を評価した。

\section{2 赤外画像熱計測システム}

本研究で構築した赤外画像熱計測システムの概要を Fig. 1 に，仕椂をTable 1 に示す．撮像には赤外カメラ（三菱社製 サーマルイメージャ, SR-1), 熱源にはホットプレート（ア ズワン社製）を用いた。赤外画像は，画像入力ボード（ライ ブラリー社製，ひまわり PCI）を介してパーソナルコンピュー 夕に入力され, 多機能沉用画像解析ソフト（ライブラリー社 製，Cosmos32）により解析される。解析に供する赤外画像 の画素数は $320 \times 240$ である. 計測の際には, 実験室内の気 流の影響を防ぐため装置全体を遮蔽板で覆った。

\section{3 計測方法}

繊維製品における熱移動特性評価法として, 本研究では吸

* 連絡先 : 信州大学繊維学部繊維システム工学科 386-8567 上田市常田3-15-1, E-mail: zawa@ giptc.shinshu-u.ac.jp, Fax: +81-268-21-5603 


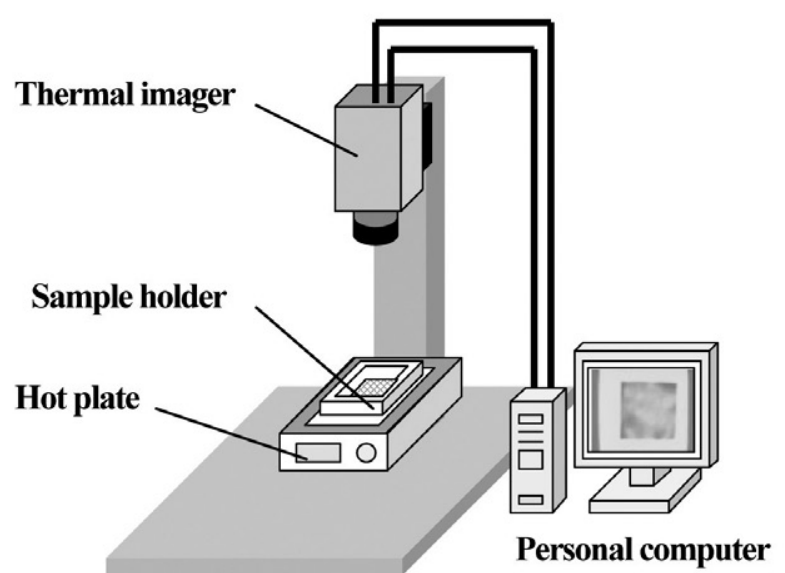

(a) Heat measurement apparatus for Infrared spectral image.

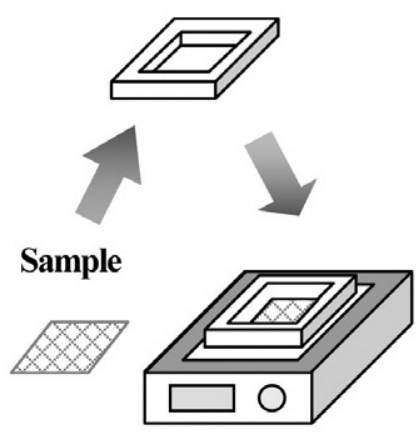

(b) Heat absorption horizontal method.

\section{(c) Heat radiation}

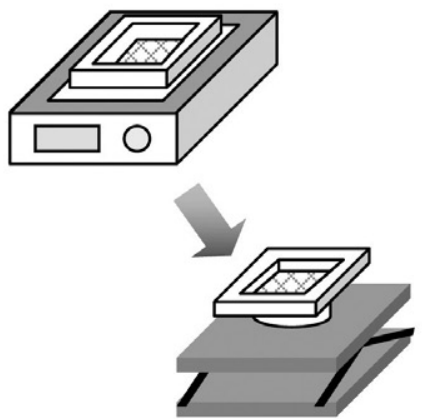

Support stand

horizontal method.

Fig. 1 Measuring system and methods

Table 1 Specification of the measuring system.

\begin{tabular}{|c|c|l|}
\hline \multicolumn{2}{|c|}{ Element } & \multicolumn{1}{c|}{ Specification } \\
\hline \multirow{2}{*}{$\begin{array}{c}\text { Infrared } \\
\text { camera }\end{array}$} & Thermal imager & SR-1, (MITUBISHI corp.) \\
\cline { 2 - 3 } & Wave length & $8 \mu \mathrm{m} \sim 12 \mu \mathrm{m}$ \\
\hline \multirow{4}{*}{ Heat source } & Hot plate & ND-3 (ASONE corp.) \\
\cline { 2 - 3 } & Power & $1370 \mathrm{~W}$ \\
\cline { 2 - 3 } & Temperature & $\begin{array}{l}\text { Room temperature }+10^{\circ} \mathrm{C} \\
\sim 350^{\circ} \mathrm{C}\end{array}$ \\
\hline
\end{tabular}

熱性について評価を行うものを, 吸熱水平法, 放熱性につい て評価を行うものを，放熱水平法とそれぞれ定義した。

吸熱水平法では，試料を発泡スチロール製の試料台にすき 間なく貼り付け， $40{ }^{\circ} \mathrm{C} に$ 保ったホットプレート上に置き， 上部に配置されたサーマルイメージャによって吸熱に伴う温 度上昇を測定することで，熱伝導性について検討した。

放熱水平法では，試料を試料台にすき間なく貼り付け $40{ }^{\circ} \mathrm{C}$ に保ったホットプレートに乗せ，5分間熱を供給した後， 試料台をガラスシャーレを用いた試料ステージ上に置き，上 部に配置されたサーマルイメージャによって放熱に伴う温度 降下を測定することで，放熱性について検討した。

本論文の趣旨は, 赤外画像計測の繊維分野への適用を提案
Table 2 Details of woven fabrics.

\begin{tabular}{|c|c|c|c|c|c|}
\hline \multirow{2}{*}{ Material } & $\begin{array}{c}\text { Weight } \\
\left(\mathrm{g} / \mathrm{m}^{2}\right)\end{array}$ & \multicolumn{2}{|c|}{$\begin{array}{c}\text { Yarn dencity } \\
(\mathrm{ends} / 5 \mathrm{~cm})\end{array}$} & \multicolumn{2}{|c|}{$\begin{array}{c}\text { Yarn count } \\
\text { (tex) }\end{array}$} \\
\cline { 2 - 6 } & & Warp & Weft & Warp & Weft \\
\hline Wool & 100 & 142 & 136 & 19 & 15 \\
\hline Silk & 53 & 264 & 190 & $2.3 \times 3$ & $2.3 \times 4$ \\
\hline Cotton & 97 & 141 & 135 & 20 & 16 \\
\hline
\end{tabular}

することである。そのため，主に衣服に用いられる天然繊維 3 種類を試料に用い, 熱移動特性評価の可能性・妥当性につ いて検討した. Table 2 に試料の詳細を示す. 各試料の色に ついて, 絹, 綿は白色であり, ウールは薄いベージュ色のも のを用いた，なお，絹番手の “ $2.3 \times 3$ ” は，番手数 2.3 の絹単 糸が3本撚り合わせられていることを表す．実験に用いる試 料片は $100 \mathrm{~mm} \times 100 \mathrm{~mm}$ とし, 試料片中央 $50 \mathrm{~mm} \times 50 \mathrm{~mm}$ 部

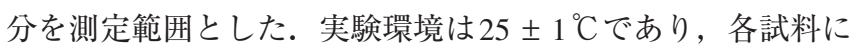
つき 10 回ずつ測定を行い，毎秒 10 コマの撮影間隔で 1 分間 撮影した後, 得られた平均輝度を温度換算し, 放射率補正を 行うことで，各試料の熱伝導性・放熱性について検討した。

\section{3. 実験結果および検討}

\section{1 赤外画像における温度換算}

Fig. 2 に $25^{\circ} \mathrm{C}, 40{ }^{\circ} \mathrm{C}$ における蒸留水の赤外画像を表す。画 像中央の円形部分が蒸留水の存在する部分であり，温度が低 い領域は輝度が低いため画像は暗く, 温度が高い領域は輝度 が高く明るくなっていることが確認できる.

Fig. 3 はサーマルイメージャにおける温度と相対輝度の関 係を表したものである，モデル試料には蒸留水を用い，同一 画像内で異なる温度の蒸留水の輝度を比較することで, 様々 な温度における蒸留水の相対輝度を得た．温度の測定範囲は 日常生活を考慮して $25 \sim 40{ }^{\circ} \mathrm{C}$ とた。また，相対輝度は $25^{\circ} \mathrm{C}$ の場合を 1 に規格化してある. 図中のエラーバー[4]は蒸 留水の平均輝度の標準偏差をとったものであり, $\mathrm{R}^{2}$ は決定係 数を表す.

温度と相対輝度の間には高い相関が得られ，直線的比例関

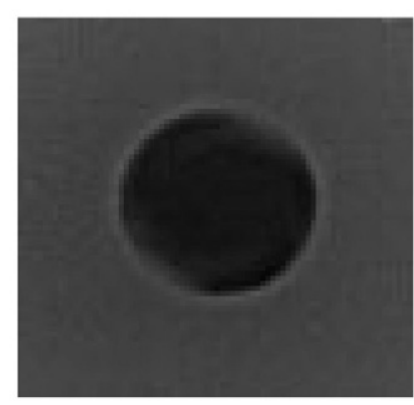

$25^{\circ} \mathrm{C}$

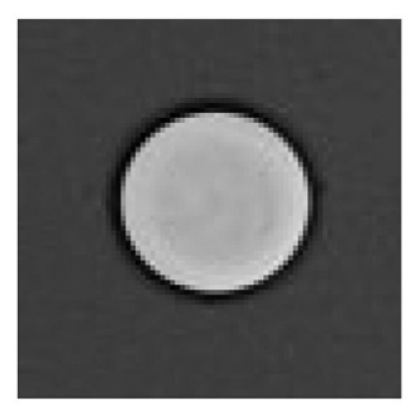

$40^{\circ} \mathrm{C}$
Fig. 2 Thermal images of the distilled water. 


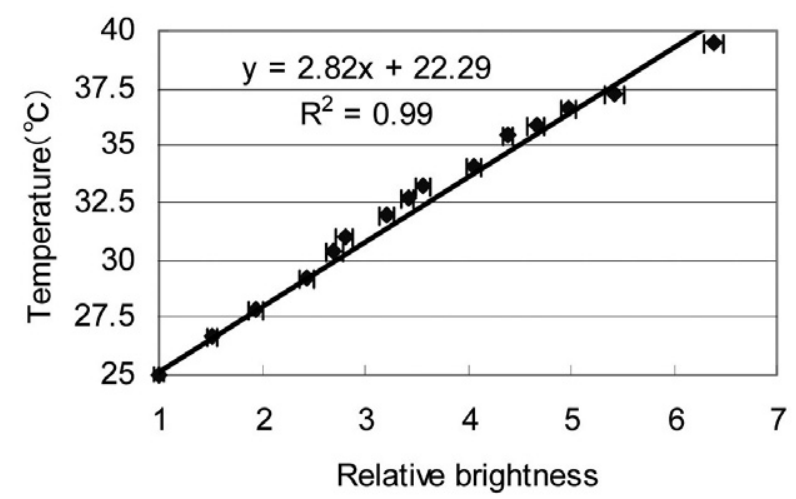

Fig. 3 Property of thermal imager.

係が見られたことから, 相対輝度から温度を求めることが可 能であると考えられる。

\section{2 放射率測定}

サーマルイメージャによって得られた画像は赤外線の放射 量を表示しており, 温度を直接表現しているわけではない. そのため, 試料の温度を求めるには各試料の放射率を求め, 放射率補正を行う必要がある。

放射率を測定するため，同じ温度の蒸留水と試料を同一画 像内に取り込み, 輝度の比較を行った。 そして蒸留水の放射 率 0.96 を基準として, 各試料における放射率を算出した。 25 , 30，35，40 ${ }^{\circ} \mathrm{C}$ で測定を行い，各温度における放射率がほぼ 同じ值を示したため, その平均值を採った. Table 3 に各試 料に打ける $25,30,35,40{ }^{\circ} \mathrm{C}$ の放射率の平均值を記す。以 下の実験では，この平均值を用いて放射率補正を行った。

\section{3 熱伝導性評価}

吸熱水平法によって熱の吸収を測定した赤外画像の例を Fig. 4 に, 画像から算出した吸熱性の時間変化を Fig. 5 に示す. Fig. 4ではモデル試料として綿試料を用いた。画像上の黒枠 は処理領域を表し, 温度は, 相対輝度を温度換算し, 放射率 補正を行った值である。また，吸熱に伴う温度上昇において， 各瞬間毎に直前のサンプリングとの差分を取ることで, 各瞬 間における吸熱速度が得られ，これをFig. 6に示す。これは KESのq-max 測定（冷温感測定）における熱吸収速度と対応 している. Fig. 6より, 吸熱速度は試料に熱が供給され始め た後, 一瞬遅れてピークを迎えた後ゆるやかに減少してゆく. このピーク值は各試料の最大吸熱速度を表し，KESにおける q-max 值に対応した值である.ピークが現れる理由として, 試料をホットプレートに乗せた瞬間は熱が伝わりきっていな

Table 3 Average of radiant ratio in sample.

\begin{tabular}{cc}
\hline Sample & Radiant ratio \\
\hline Wool & $0.91( \pm 0.01)$ \\
\hline Silk & $0.88( \pm 0.03)$ \\
\hline Cotton & $0.89( \pm 0.01)$ \\
\hline
\end{tabular}

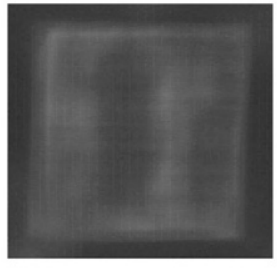

0.1s

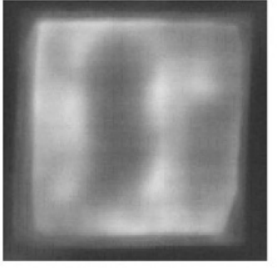

$5 s$

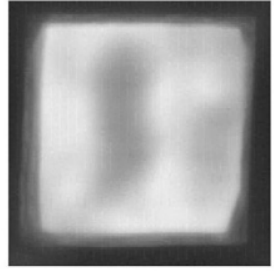

$10 \mathrm{~s}$
Fig. 4 Thermal images in the heat absorption.

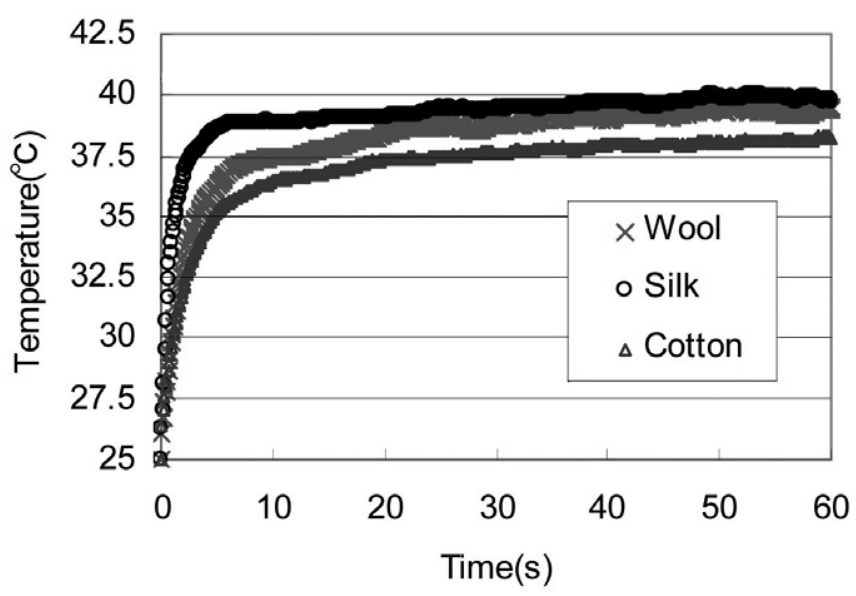

Fig. 5 Time-dependence of the heat absorption.

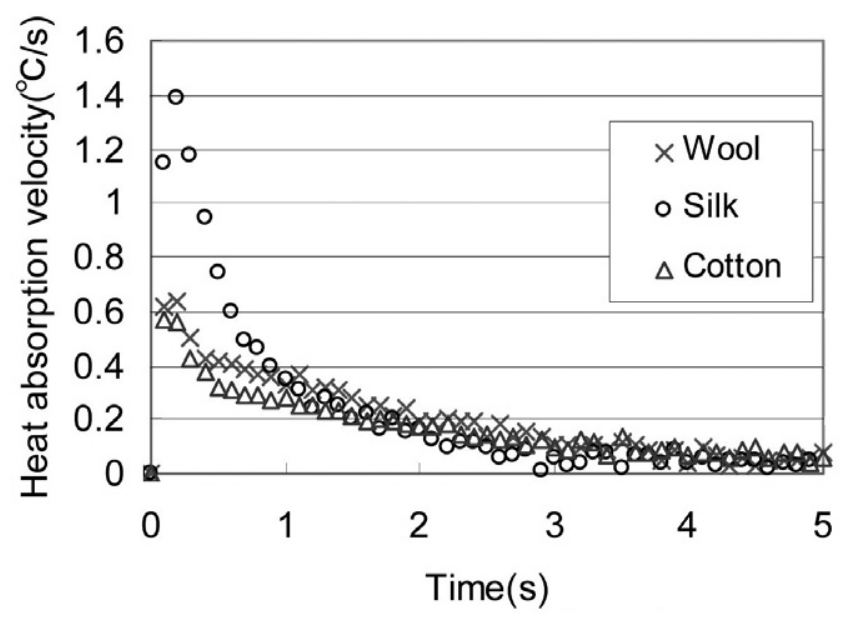

Fig. 6 Time-dependence of the heat absorption rate.

いため，一瞬遅れて吸熱速度が最大となる。そして吸熱が進 むにつれてホットプレートと試料との温度差が小さくなり， 吸熱速度が小さくなっていく，そのため，吸熱開始から一瞬 遅れてピークが現れると考えられる.

吸熱過程において，織密度・番手・目付けにおいてほぼ同 じ值を持つウールと綿の間に, 明確な差が確認することがで きた。この差は, 素材そのものに起因するものと考えられる. しかし, 今回の研究では素材の比較だけでなく, 繊維製品の 熱移動特性評価への適用が可能か否かという広い観点におい て熱移動計測を行ったため, 今回の3 試料を用いた実験結果 のみから素材の差違を述べることには無理があると考えられ る. そのため, 今後, システムの実用性を検討する上で, よ り多くの様々な繊維製品を試料に用いて計測を行い，布の表 
面構造, 空気の含有構造といった要素が熱伝導率にどのよう に関連しているかを検討した上で, 改めて素材間の比較を行 う必要がある。

また，同一試料を用いて KESにおける熱吸収速度測定を 行った。測定には精密迅速熱物性測定装置（カトーテック社 製KES-E7 THERMO LABO II ）を用いた. その結果，絹，ウー ル, 綿の順に $\mathrm{q}-\mathrm{max}$ 值が大きいという結果が得られた. 絹の q-max 值がウール, 綿に比べて大きく, ウールと綿の q-max 值が近い值であるという点において，本手法の結果（Fig. 6） と KES 法の結果で同様の傾向を得ることができた.さらに， 本システムでは時系列的に吸熱速度を求めることができた。

吸熱性は熱の伝わり易さを表すため, このことから, 熱伝 導性の時系列的な定性・定量評価の可能性が見出せた.

\section{4 放熱性評価}

放熱水平法によって熱の放射を測定した赤外画像の例おお び画像から算出した放熱性の時間変化を Fig. 7 およびFig. 8 に示す. Fig. 7ではモデル試料として綿試料を用いた。画像 上の黒枠は処理領域を表し, 温度は, 放射率補正を行い, 相対 輝度から算出された值である. また, 放熱に伴う温度上昇にお いて, 各瞬間毎に直前のサンプリングとの差分の絶対值を取 ることで得られる, 各瞬間における放熱速度を Fig. 9 に示す.

ウールが高い放熱性を持つ理由として, ウール表面のクリ ンプにより, 空気が蓄積しやすく熱が保たれるためと考えら れる[5]. また, 吸熱性の良い試料が放熱性が良いとは限ら ないことから，必ずしも熱伝導性・放熱性の間に関連性はな いと考えられる。

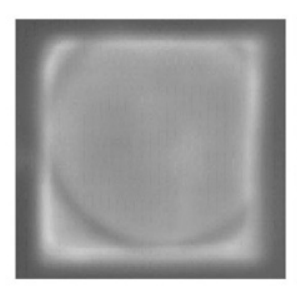

$0.1 s$

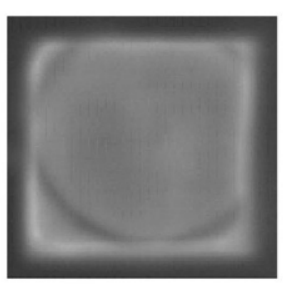

$5 s$

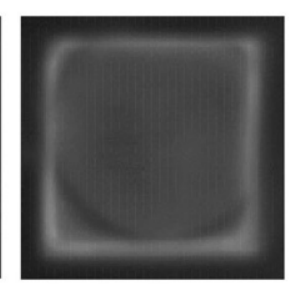

10s
Fig. 7 Thermal images in the heat radiation.

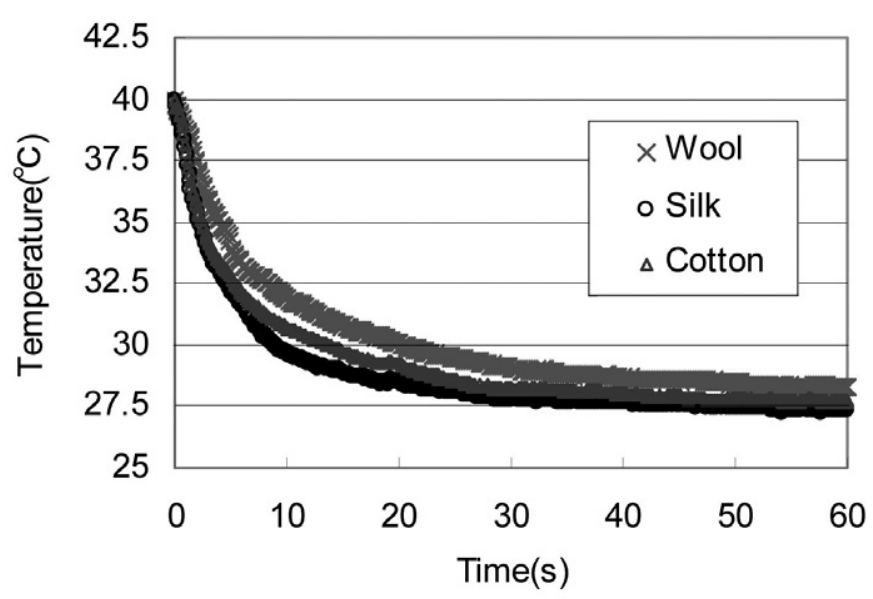

Fig. 8 Time-dependence of the heat radiation.

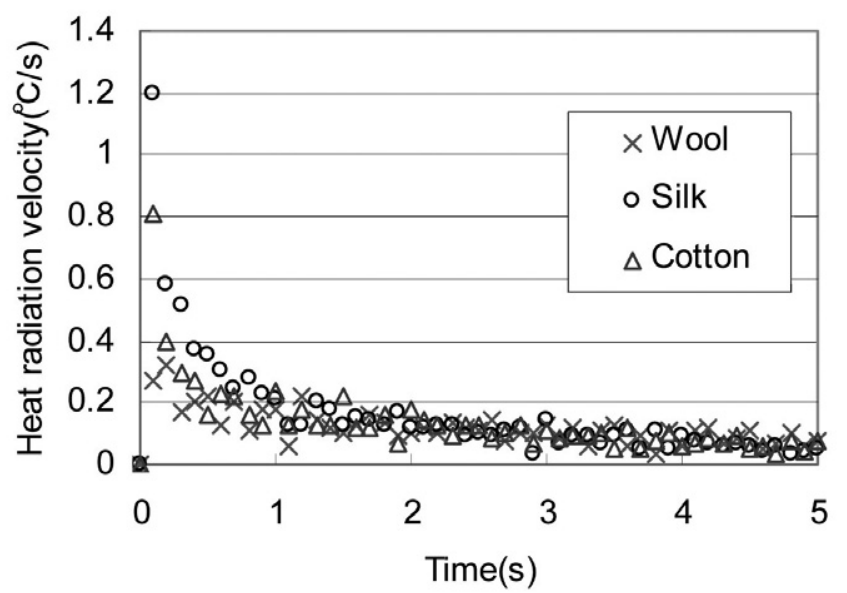

Fig. 9 Time-dependence of the heat radiation rate.

\section{4. 熱移動特性に関するパラメータ}

繊維製品における熱移動特性の一つの指標として，各試料 の熱伝導性，放熱性におけるパラメータ（伝熱係数）を検討 した。すなわち，熱伝導性実験結果より得られた，吸熱直後 $1 ， 5 ， 10$ 秒間の温度変化量をもとに, 温度変化量をもとに, (1)式のフーリエの法則[6]を用いて伝熱係数を算出した.

$\frac{q}{A}=-k \frac{d x}{d t}$

ここで, $\mathrm{k}$ は熱伝導率, $\mathrm{q}$ は熱移動量, $\mathrm{A}$ は測定領域の面積, Tは温度勾配， $\mathrm{x}$ は試料厚さとする.

Table 4 に各試料の吸熱開始後 1，5，10秒間の熱伝導性に 関するパラメー夕（熱伝導性に関する伝熱係数）を記す。熱 移動量は, $25^{\circ} \mathrm{C}$ の際の水の熱伝導率 0.52 [7] 用いて蒸留水 $10 \mathrm{ml}$ の温度変化より算出したものであり, 面積は $100 \mathrm{~mm}^{2}$, 試料厚さは各試料を構成している糸の太さの 2 倍の值とし た。この值が大きいほど熱伝導性が良く, 絹, ウール, 綿の 順に熱伝導性が良いことがわかる.

また，Table 5 に放熱開始後 $1 ， 5 ， 10$ 秒間の放熱性に関す るパラメータ（放熱性に関する伝熱係数）を記す。放熱性実 験結果より得られた，放熱直後の $1 ， 5 ， 10$ 秒間の温度変化

Table 4 Parameter concerning thermal conductivity(W/mK).

\begin{tabular}{cccc}
\hline Sample & $1 \mathrm{~s}$ & $5 \mathrm{~s}$ & $10 \mathrm{~s}$ \\
\hline Wool & 0.17 & 0.11 & 0.10 \\
\hline Silk & 0.32 & 0.13 & 0.10 \\
\hline Cotton & 0.14 & 0.09 & 0.08 \\
\hline
\end{tabular}

Table 5 Parameter concerning heat radiation(W/mK).

\begin{tabular}{cccc}
\hline Sample & $1 \mathrm{~s}$ & $5 \mathrm{~s}$ & $10 \mathrm{~s}$ \\
\hline Wool & 0.04 & 0.06 & 0.07 \\
\hline Silk & 0.08 & 0.15 & 0.16 \\
\hline Cotton & 0.07 & 0.08 & 0.09 \\
\hline
\end{tabular}


量をもとに，(1)式のフーリエの法則[6]を用いて放熱係数を 算出した。熱移動量は, $40{ }^{\circ} \mathrm{C}$ の際の水の熱伝導率 0.54 [7]を 用いて蒸留水 $10 \mathrm{ml}$ の温度変化より算出したものであり, 面 積は $100 \mathrm{~mm}^{2}$, また試料厚さは各試料を構成している糸の太 さの 2 倍の值とした。この值が大きいほど放熱性が良く, 絹, 綿, ウールの順に放熱性が良いことがわかる. また，同一試料 を用いて KESによる定常熱伝導性測定, 保温性測定を行っ た. 測定には精密迅速熱物性測定装置（カトーテック社製 KES-E7 THERMO LABO II ）を用いた. その結果, 絹, ウール， 綿の順に熱伝導性が良く, 絹, 綿, ウールの順に放熱性が良 いといった結果が得られ，本システムにおける実験結果と同 じ傾向が見られた。したがって，本手法はKES と比較して 簡便かつ迅速であり，KESでは得られない熱移動のメカニズ ムについて観測することができるため, 繊維製品における熱 移動特性評価として，本システムの妥当性が確認できた。

以上より，本計測システムを用いて，繊維製品の定量的か つ時系列的な熱伝導性評価, 放熱性評価が可能である. すな わち, スポーツによる体温上昇, 急激な被服の温度降下など, 日常での温度变化における被服の熱移動特性を推定すること ができ，熱移動に伴う着心地などを事前に評価する上で有用 な計測システムと考えられる。

\section{5. 結 言}

本研究では, 繊維製品における熱移動特性を評価するため の赤外画像熱計測システムを提案し，ウール，絹，綿といっ た被服の材料となる試料を用い，吸熱・放熱現象を観測し， 熱伝導性・放熱性について計測することで，計測システムの 妥当性および有用性を考察した。

本研究の主な結果は，以下のとおりである。

(1) 蒸留水における温度変化と輝度との間に直線的比例関係 が確認できた。また，各試料の熱伝導性・熱保持性について 定量的な評価が行えた。

（2）吸熱性が良い試料が放熱性が良いとは限らなかったこと から，熱伝導性と放熱性の間には必ずしも関連性がないと考
えられる。

（3）吸熱性には熱伝導性が関連しており，熱伝導性・放熱性 をパラメータ化することによって, 端的に繊維製品の熱移動 特性を評価することができた。

（4）KESにおける q-max測定，定常熱伝導性測定，保温性測 定の実験結果と同じ傾向が見られた。また，KESでは得られ ない情報を得ることができ，時系列的かつ定量的な評価を行 うことができたとともに，本システムの妥当性が確認できた.

以上のように，本システムによれば，熱移動のメカニズム を観測できるとともに，JIS，KESの評価方法では得られな い情報が入手できると考えられる，また，吸熱性には熱伝導 性が関連しており，放熱性とともに時系列的な定性・定量評 価が可能である。 そして, 熱伝導性, 放熱性をパラメータ化 することによって，端的に繊維製品の熱移動特性を評価する ことができた. 従って, 赤外画像熱計測システムを用いた緎 維製品の熱移動特性の評価方法としての可能性・妥当性が拓 かれた。

\section{References}

[1] JIS L 1096-1999 "Test methods for ordinary woven fabrics (Heat insulation)", pp48-49

[2] Kawabata S (1984) J Text Mach Soc Japan, 37, T130-T141

[3] Hisano H (1994) "Infrared rays engineering", pp22-23, Electronic information communications society

[4] Hayashi S, Baba R (2000) "An introduction to error analysis in the measurement", pp109-110, Tokyo chemical coterie

[5] Nakazima T (2001) "Outline of the clothing material", pp114123, Kouseikan

[6] Houzawa M (1996) "Diffusion and movement phenomenon", pp50-51, Chemical engineering association

[7] Hagi H (1978) "Basis and practice of the heat transmission", pp66-78, Toukai University publication society 